DE DE GRUYTER OPEN
Journal of Intercultural Management

Vol. 6, No. 3, September 2014, pp. 17-35

DOI 10.2478/joim-2014-0017

Adela Barabasz*

Wroclaw University of Economics

Mieszko Kuźmierz*

Graduate Degree Business Administration

\title{
Perception of organizational culture, commitment and loyalty of corporation employees
}

\begin{abstract}
The article is of empirical nature. It presents the results of research dedicated to identification of the organizational culture and the commitment of the employees of an international corporation operating on the financial services market. The OCAI questionnaire, used to identify the dominant type of organizational culture, and a questionnaire concerning the commitment and loyalty of employees in three selected branches of the company, located in Poland, England and India, were used in the research.

The main aim of the research was to identify the types of the organizational culture and to define the level of commitment of employees and loyalty, taking into account factors like branch location and nationality of the surveyed people. The assumption that organizational culture is positively correlated with the level of commitment and loyalty has been only partially confirmed and requires further verification. However, the differences between the results from the three branches (Poland, India, England) encourage continuation of that type of research.
\end{abstract}

Key words: organizational culture, commitment, loyalty, management

\section{Introduction}

The article is dedicated to the issues of organizational culture and its impact on the shaping of employee attitudes, such as commitment and loyalty. Contemporary companies more and more often declare that it is worthwhile to invest into

*adela.barabasz@ue.wroc.pl; mieszko.kuzmierz@gmail.com 
and consciously shape the attitude of commitment among employees. The attitude contributes to enhanced productivity, which directly translates into the company's performance, a growth of its competitive position and market success. Highly motivated organization members work not only more efficiently, but also manifest greater loyalty towards the employer, which has also an impact on the continuity of employment (low staff turnover). Therefore, committed and loyal employees determine not only market success, but also have a direct impact on reduction of costs related to seeking new personnel, investing in their training and the induction processes.

Looking for the sources of employee commitment, one cannot omit the issue of organizational culture. For an organization with global reach, operating on geographically differentiated markets, organizational culture, including the features of national cultures, is a problem of uncontested importance. The presented article undertakes to identify relations between organizational culture and readiness to manifest behaviours testifying to employees' commitment to the affairs of the organization and manifestation of the attitude of loyalty towards it.

This article is of empirical nature. It presents the results of studies dedicated to identification of the type of organizational culture and assessment of the level of commitment of employees of a financial institution of international reach.

The main aim of the conducted research was to identify the connections between the type of organizational culture and the level of commitment and loyalty of employees, taking into account variables like branch location and nationality of the subjects. The surveys employed the OCAI questionnaire, used to identify the dominant type of organizational culture, and a questionnaire concerning the commitment of employees in three selected branches of the company, located in Poland, England and India.

\section{Role of organizational culture on commitment and loyalty of employees -theoretical background}

Research on organizational culture has a long and rich tradition. This article is based on the assumption that organizational culture is a set of (formal and informal) norms and values which shape the conduct of its members; they have an important impact on efficiency and implementation of formal tasks of an organization [see: Hofstede, 2000; Juang, Matsumoto, 2010; Schein, 2004; Sikorski, 2002].

Considering organizational culture to be the source of efficiency of the company, K. Cameron and R. Quinn differentiated four of its types: hierarchy oriented cultures, market oriented cultures, clan oriented cultures, and adhocracy oriented cultures [Cameron, Quinn, 2003]. The authors define the dominant employee attitudes, group management styles and motivation methods. Thus, the hierarchy culture features highly formalized norms and procedures, where greater predict- 
ability and efficiency are strived at. The market culture is characterized by an emphasis on external issues, cooperation with external entities, attempting at maintenance of long-standing clients. Leaders of an organization oriented on the market are ambitious and demanding, and members of the organization are bound by the common goal of obtaining a superior position on the market. In the clan culture, employees are characterized by common beliefs, converging values and goals, high level of commitment and integration; teamwork and shared responsibility are the hallmark. High importance is attributed to a friendly atmosphere, which is supposed to improve the commitment and loyalty of the members, and the leader is the mentor who exercises care, builds an atmosphere of assistance, respect for tradition. As regards the adhocracy culture, it is based on close watch of the competitors and introduction of innovation. Organizations of this type are oriented on creative solutions; they esteem task-orientation and individual competences. In adhocracy, visionaries willing to experiment and implement innovative solutions are sought, and their goal is to develop unique goods.

According to R. Quinn and K. Cameron, the type of organizational culture changes along with the development of the organization according to the following pattern: first, there appears the dominant type of hierarchy culture, then the market culture, next the clan culture, and finally the adhocracy culture [Cameron, Quinn, 2003].

The type of organizational culture is directly linked to the issue of commitment, especially commitment to work, at the same time referring to the individual and personality characteristics of employees. In the literature, beside the general concept of commitment, there also appears the term 'organizational commitment', used mostly with reference to commitment of an employee to the organization and identification with it. Manifestations of commitment include defending the organization against criticism, the feeling of loyalty, long-term attachment to the organization, readiness to devote one's own time for organization's purposes, enthusiasm, determination to overcome obstacles, appropriate attitude and activity [Bugdol, 2006, p. 9]. Usually, greater commitment means stronger identification with the company and enhanced job satisfaction [Schultz, Schultz, 2008; Gajdzik 2009, pp. 23-30]. J.P. Meyer, N.J. Allen and A.C. Smith [1993, pp. 538-551] assert that organizational commitment is composed of affective commitment, continuance commitment, and normative commitment, that is commitment resulting from social norms, building the feeling of obligation and loyalty. The research reveals that employees with a high level of affective commitment are more valuable for the organization due their greater contribution of work and achieving better performance. Normative commitment gives slightly poorer effects and, just like the continuance commitment, is more susceptible to "absenteeism and fluctuation". Employees with a high degree of continuance commitment are worse at implementing tasks and have lower integration capabilities [Markowski et al., 2010, p. 7]. 
The problem of employee commitment in the light of the organizational culture becomes particularly significant in organizations which employ people who represent different nationalities, diverse value systems, and culturally determined behaviours. At the time of globalization of markets and implementation of international projects, organizations are facing the challenge of finding the optimum solutions in situations, when employees who sometimes represent extremely different patterns of behaviour and cultural norms meet in one organization, under one roof. Studies show the complexity of the mutual adaptation process between employees, representing different nationalities, and thus more or less different cultural elements are becoming increasingly important.

The studies, whose results are presented below, were carried out to find an answer to the question of the impact of organizational culture on unification of the conduct of employees in a multinational corporation and to consider the dominant type of culture depending on the location of the branch forming part of the corporation.

\section{Methodology and results of the research}

The aim of the empirical research was to identify the dominant type of organizational culture and to define the relationship between the type of organizational culture and the level of commitment of employees of different nationalities employed in the three branches, located in different countries (England, Poland, and India).

The research verified the following hypotheses:

H1. The organizational culture of the subject company is homogenous, regardless of location of the branch.

$\mathrm{H} 2$. The nationality of the respondents differentiates employees in terms of the level of commitment and loyalty.

H3. The branch location does not differentiate employees in terms of the level of commitment and loyalty.

\section{Description of the research}

The research was based on the OCAI questionnaire and a survey that measured the level of commitment of members of the organization. The survey also included questions regarding demographics, branch location, nationality of the employee and the current position in the company (corporate title). The OCAI Questionnaire (Organizational Culture Assessment Instrument) examines the existing type of organizational culture (current and desired) against four types of organizational culture: the culture of clan, adhocracy, hierarchy and market. The survey and the questionnaire were sent electronically in the beginning of 2014, with emphasis on their anonymous nature. All employees who took part in the research were working for sales support on London Stock Exchange. 


\section{Description of the test subject}

The study was conducted in a financial company founded in Switzerland in 1856. It has been developing rapidly from the beginning, currently spanning all continents. Its main areas of business are: Private Banking, Asset Management, and Investment Banking. The company offers a wide range of financial services, manages capital investments in exchange transactions (shares, bonds). Furthermore, company X provides financial services to retail clients. The investment banking division provides services related to a variety of financial products, customer-oriented (companies, corporations, governments), making available acquisition of attractive investment sources that provide long-term safe profits to clients.

The company hires more than 45,000 people worldwide. In more than 50 countries, it operates over 300 branches, including four Centres of Excellence, one of which is located in the United States, two in India, one in Wroclaw. The Wroclaw branch was opened in 2007, initially employing 500 people. Until now, the number of employees has exceeded 1,500 people and keeps growing.

The company's strategy is based on six pillars:

- Customer - the most important one; aiming at establishment of consistent, trustworthy relationships with clients, active listening and identification of customer needs, and seeking appropriate solutions.

- Employees - Company Xis trying to attract the best people, offering opportunities and prospects that will benefit both the employee and the organization on many levels.

- Capital and risk management - prudent and wise in taking the risk, the pursuit of conservative management of liquidity and capital; the bank seeks to strengthen the capital base with an emphasis on additional issuance of conditional capital and the reduction of risky assets.

- Efficiency - essential for top performance, while fostering the reputation; implemented measures aimed at increasing productivity through emphasis on generating savings and developing a culture of efficiency.

- Cooperation - close cooperation between departments and regions is essential for delivering comprehensive solutions to complex financial needs of customers; carried out to measure and control the collaboration between internal business units.

- Responsibility - the company strives to take responsibility for every aspect of their business.

\section{Characteristics of the respondents}

The studies involved 91 employees of Company $\mathrm{X}$ from its 3 branches (30 people working in the London branch, 31 in India and 30 in Wroclaw). Amongst the respondents, there were people from England, India, Polish, Brazil, Germany, 
Ukraine and Australia. Respondents working in Wroclaw included: 25 Poles, two Germans, a Ukrainian, a Brazilian and an Australian. In the group of 31 employees from London there were 20 Englishmen, 8 Indians, a Pole and a German. In India, a questionnaire was filled by 30 Indians and one Englishman. 49\% of respondents were male, while women accounted for $51 \%$.

Figure 1. Nationality of the respondents

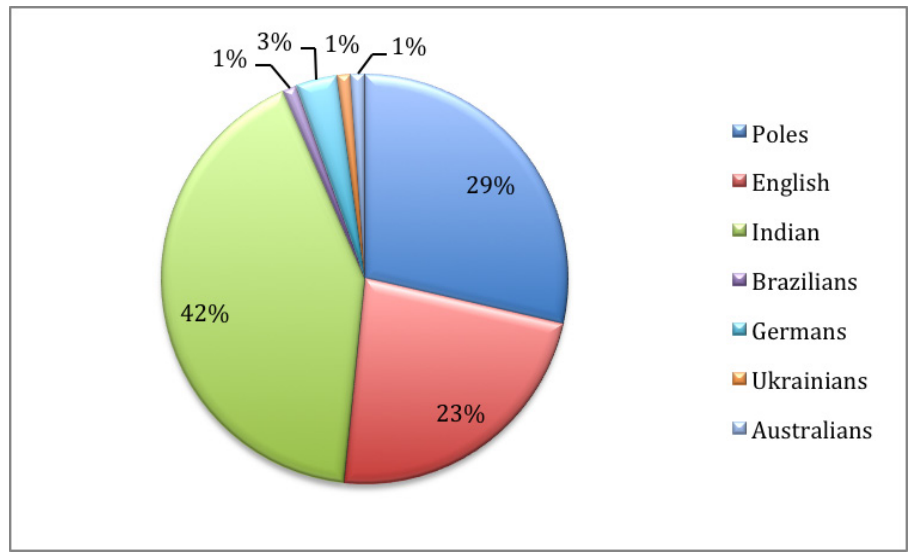

Source: Own study

Figure 2. Age of the respondents

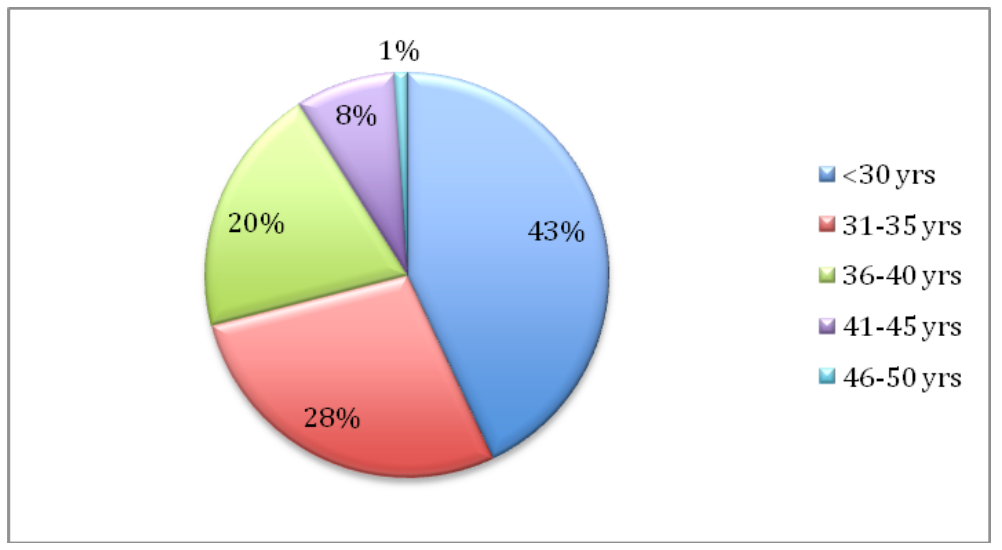

Source: Own study

In terms of age, the respondents are dominated by young people under 30. Almost three quarters of respondents are employees aged up to 35 years (71\%). Most of the younger workers are located in the Poland and India branches. The respondents from England represented all ages. 
Figure 3. Corporate titles across test subjects

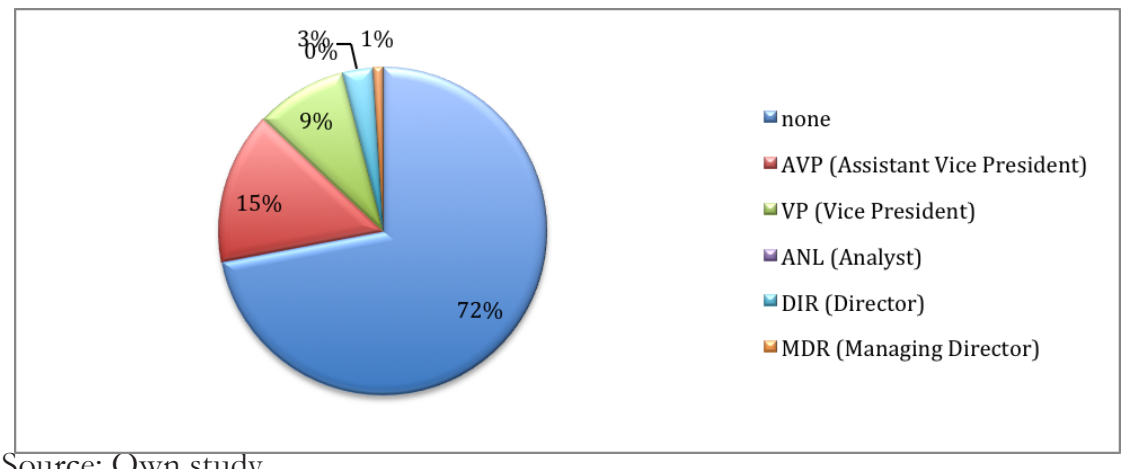

Source: Own study

The largest group of the respondents are people who do not have a corporate title, which is related to the high share of employees under 30 years of age participating in the study. Corporate titles are held by $28 \%$ of employees. Among them, relatively many (15\%) were AVPs, VPs - 9\%, DIRs - 3\% and MDRs - 1\%). The breakdown of the positions of the subjects by location is as follows:

Table 1. Corporate titles by location

\begin{tabular}{|l|l|l|l|l|l|}
\hline & AVP & VP & ANL & DIR & MDR \\
\hline Wrocław & 4 & 2 & 0 & 1 & 0 \\
\hline Londyn & 8 & 3 & 0 & 3 & 1 \\
\hline Pune & 1 & 1 & 0 & 0 & 0 \\
\hline
\end{tabular}

Source: Own study

Most of the employees that have a corporate title work in London (15 people - that is half of the subjects of this branch), and people with corporate titles accounted for the lowest share among the Pune staff (only 2 employees). The branch in Wroclaw, on the other hand, had 7 employees with corporate titles, which corresponded to around $25 \%$ of the subjects working in Poland.

The results of the OCAl questionnaire for company $X$ and its branches

An analysis of the data obtained was carried out with respect to aspects such as the dominant type of culture in the organization, the discrepancy between the current and the desired state, the strength of the dominant culture, compliance, the degree of divergence and the presence of general trends in terms of the organizational culture type measured throughout the organization. 
Figure 4. Company $\mathrm{X}$ organizational culture diagnosis

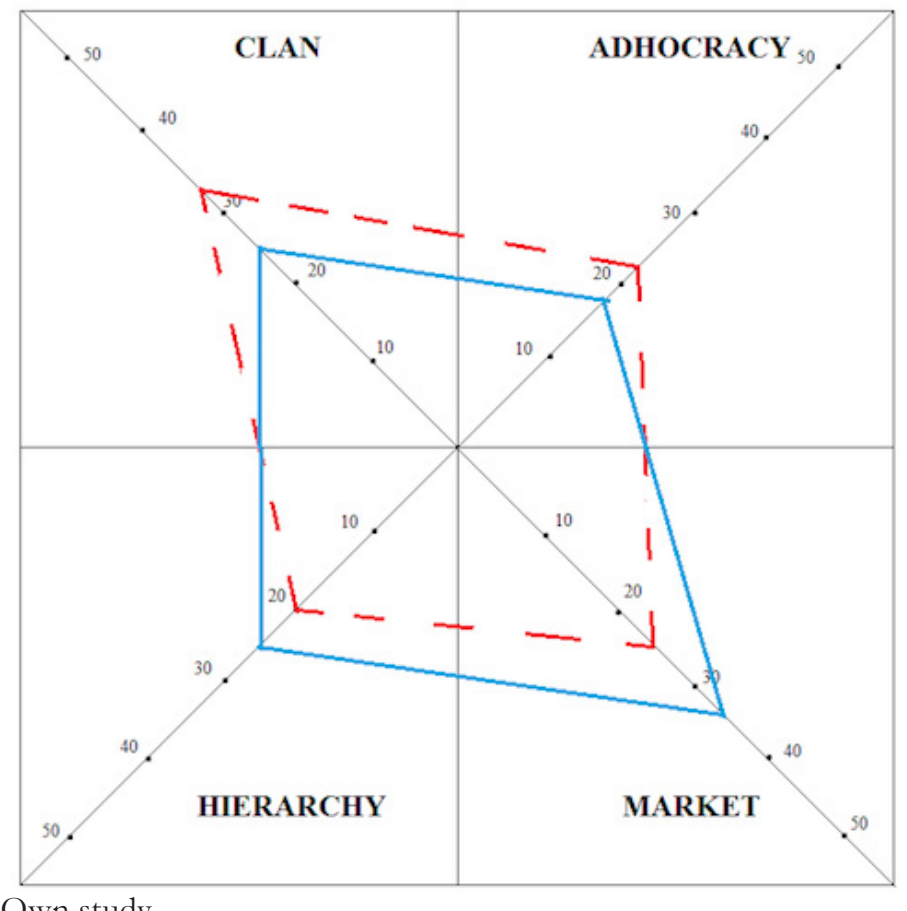

Source: Own study

The OCAI questionnaire enables specification whether the various parts (branches) are dominated by the same type of culture, and thus how strong and consistent the type of organizational culture in the studied company is. The results show that market culture prevails in all surveyed branches, therefore the organizational culture of the company is maintained regardless of its location and other differentiating factors (see H1). At the same time, the results of the questionnaire extrapolated to the entire Company $\mathrm{X}$ indicate the dominance of the market culture, while respondents indicate that the clan culture is the desired one; they would like to increase its importance at the expense of the significance of the market culture. The distribution of the results for particular culture types leads to the conclusion that the market culture in Company $\mathrm{X}$ is strong, although the other types are also present.

An analysis of the responses to the questionnaire shows that the trends observed in the majority of global companies are also present in the company $\mathrm{X}$; for example, the higher the position held, the greater the tendency to award more points to the clan culture and rate the adhocracy culture as the least relevant.

This study assumed a comparison of the organizational culture of the three selected branches of a Company X - branches located in Wroclaw, London and Pune (India). The results for the three branches are shown in the following charts. 
Figure 5. OCAI questionnaire results for Wroclaw

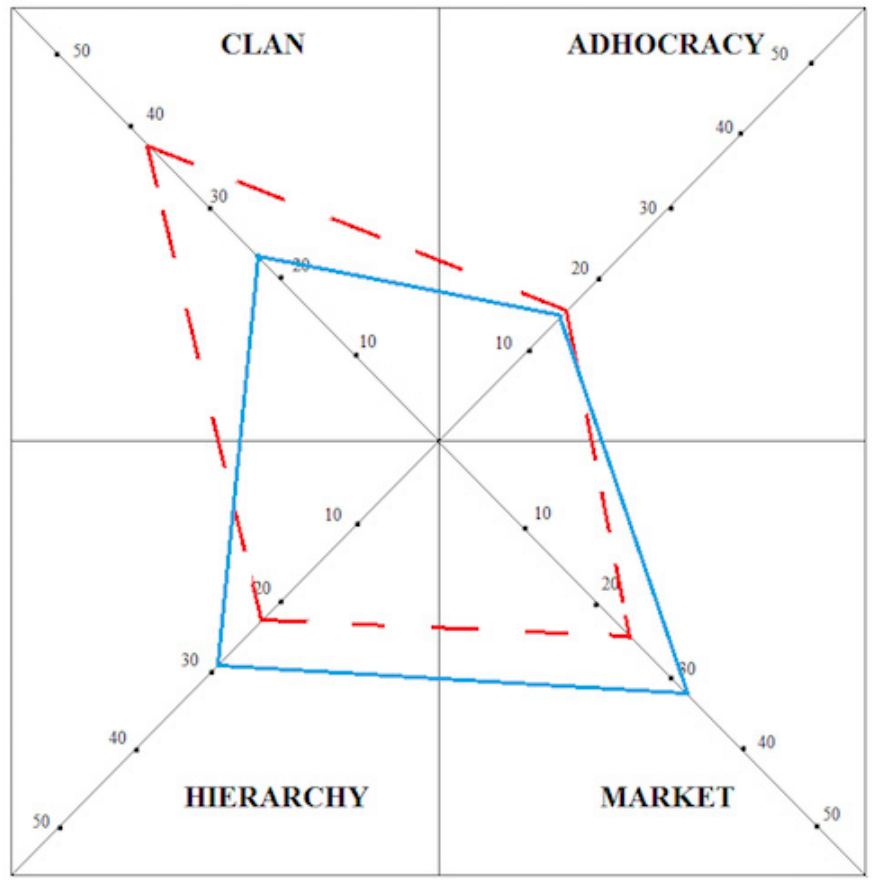

Source: Own study

The results of the branch in Wrocław show that employees stationed in Poland manifest a relatively greater need to replace the existing market and hierarchy cultures with the clan culture. There is a high discrepancy (up to 15.8 points) between the assessments of the current and the desired state (that is the clan culture). The highest level of acceptance of the current state in Wrocław was recorded with respect to the adhocracy culture, where the discrepancy amounted to just 0.9 points. Employees in managerial positions in the Wroclaw branch were pointing to the clan culture as the description of their desired vision of the company, unlike the other respondents. The current state of the company, on the other hand, was described as the market culture. Foreigners working in Wroclaw showed a trend similar to the Poles placed lower on the corporate ladder. Both categories of employees indicated the need of functioning in a friendly environment which values teamwork, as well as loyal and committed employees. At the same time, they perceived their organization as a place oriented on profits, where internal rivalry and effective execution of tasks are the measures of success. Superiors are considered to be demanding and prefer professional contacts. Wrocław employees would like to reduce the level of formality and hierarchy in the company by weakening the hierarchy culture elements. 
Figure 6. OCAI questionnaire results for Pune

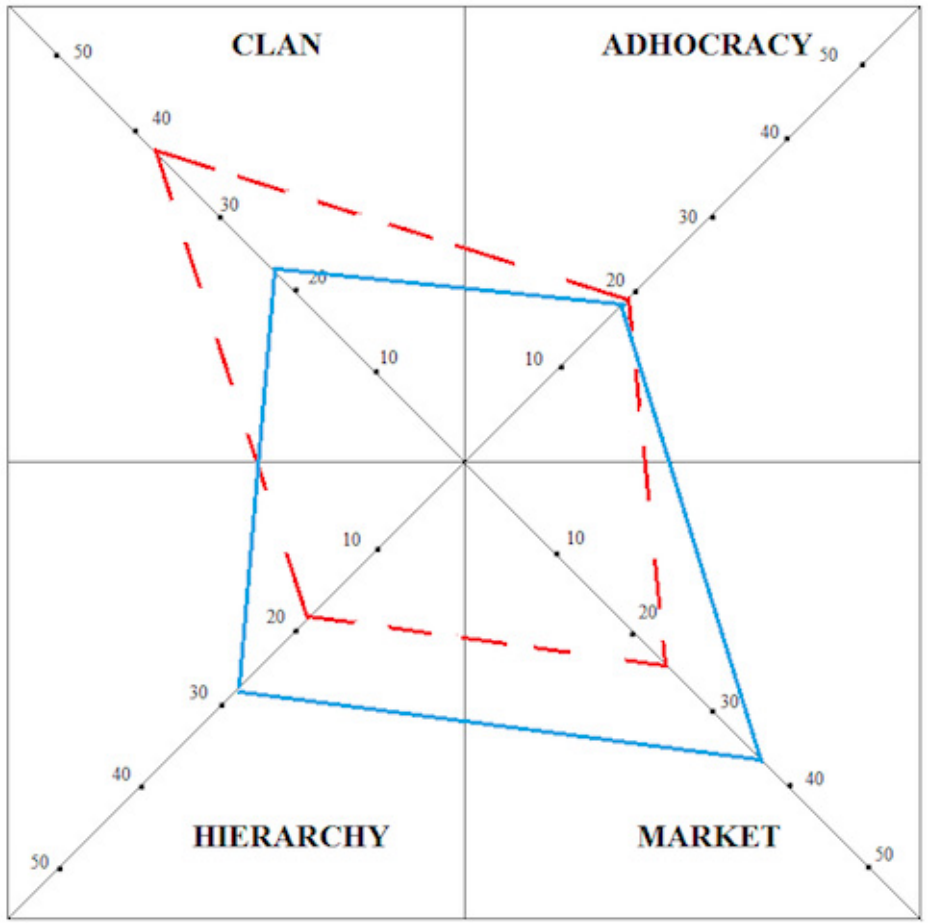

Source: Own study

The results of the respondents employed in Pune proved to be very similar to the results of the Wrocław branch, with an even greater need to strengthen the clan culture (the difference is 16.7 points). The Indians expressed the desire to reduce the degree of formality of the company, along with the perception of less need for supervisors as mentors and tutors. They wished to work in a team where everyone cares about others; this does not correspond to the focus on profit and competition, formulation of tasks and challenges. The organization's goal of attaining the dominant market position is not convincing. Respondents from Pune revealed the greatest discrepancy between the assessment of the current situation (market culture) and the desired state (clan culture). However, two English respondents occupying senior positions in the department advocated strongly for the market and hierarchy culture. 
Figure 7. OCAI questionnaire results for London

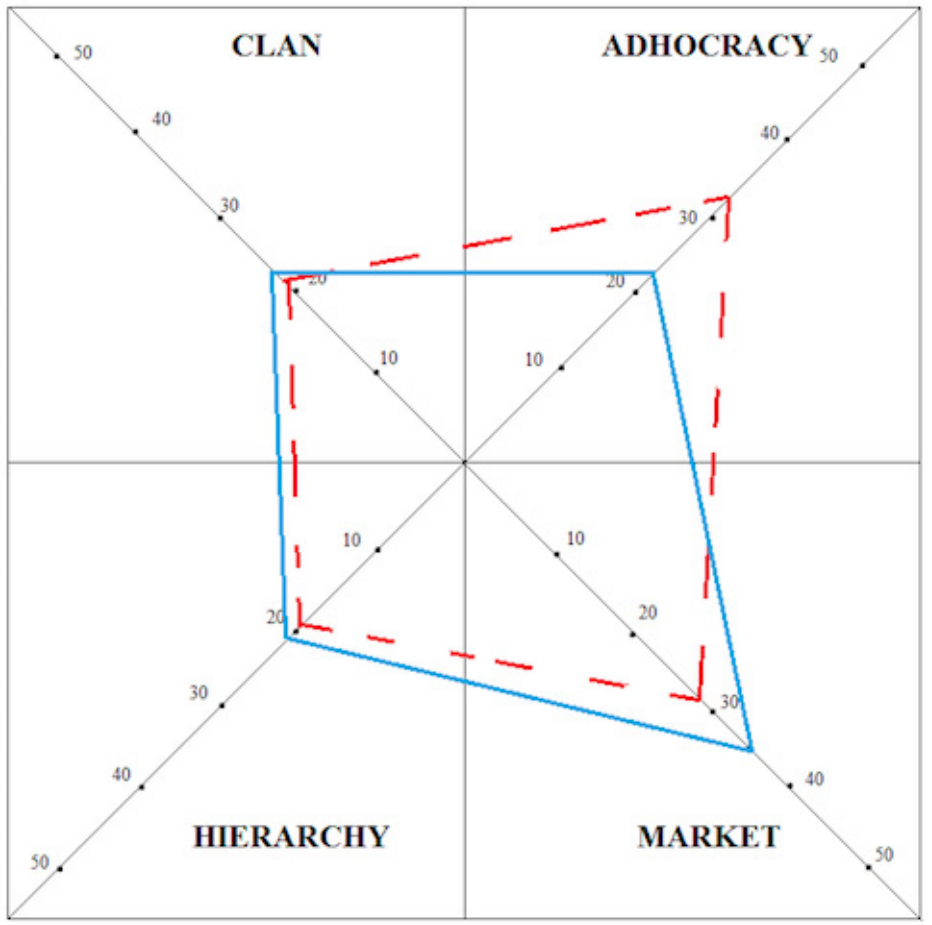

Source: Own study

The employees working in London perceive the culture of the company differently from the respondents from the both branches, Wrocław and Pune. First of all, the subjects of the London branch evaluated the cultural level of the clan as satisfactory, even with a tendency to reduce its manifestations. It can be concluded that workers in London are not looking for a friendly and family atmosphere at work, but prefer the objectives and achieving major results. Nevertheless, like other branches, they would wish to reduce the power of the market culture, at the same time identifying the adhocracy culture as the most desired. The respondents from London would like to introduce more dynamism and creativity into the organization. The existing effective level of hierarchy was sufficient for them, but they wanted greater emphasis to be placed on addressing the challenges and introduction of innovative solutions. The organization, according to them, should encourage freedom and pursuit of their own ideas. A slightly different approach was presented by the Indian people working in London. They would rather strengthen the clan culture, similarly as their colleagues working in Pune. 


\section{Commitment and loyalty of Company $\mathrm{X}$ - survey results}

It was assumed that the positive assessment of the company as a workplace, knowledge of strategic objectives and willingness to dedicate free time to the company are indicators of employee commitment. On the other hand, the sense of attachment and identification with the company, readiness to switch roles, and positive assessment of the development opportunities offered by the company are the manifestations of employee loyalty. Below are the results obtained in the survey.

Figure 8. Would you rate your company as a good place to work?

Source: Own study

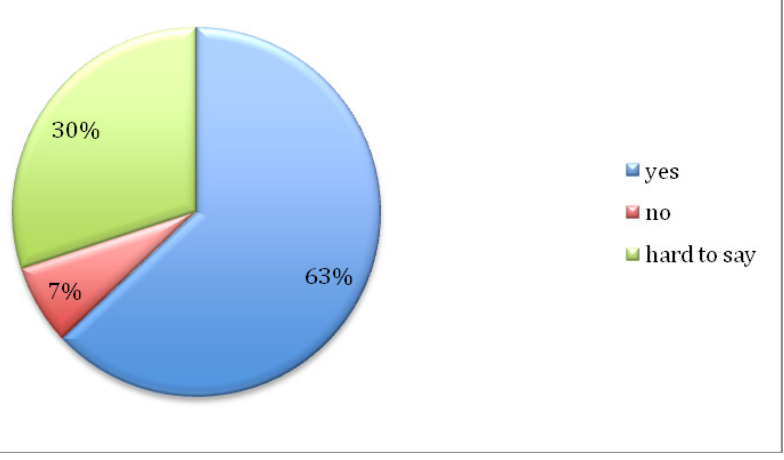

Most respondents stated that they considered Company X to be a good employer. Employees of the London branch and foreigners occupying managerial positions in Wroclaw and Pune expressed a positive evaluation Company X, also the Poles most often depicted X as a good place to work. Relatively many negative or neutral responses were found among the Indians and older workers (41-50 years) that did not hold managerial positions.

\section{Knowledge of strategic objectives of the company}

Employee commitment is also measured by the knowledge of company's strategic goals. 
Figure 9. Familiarity with company's strategic goals

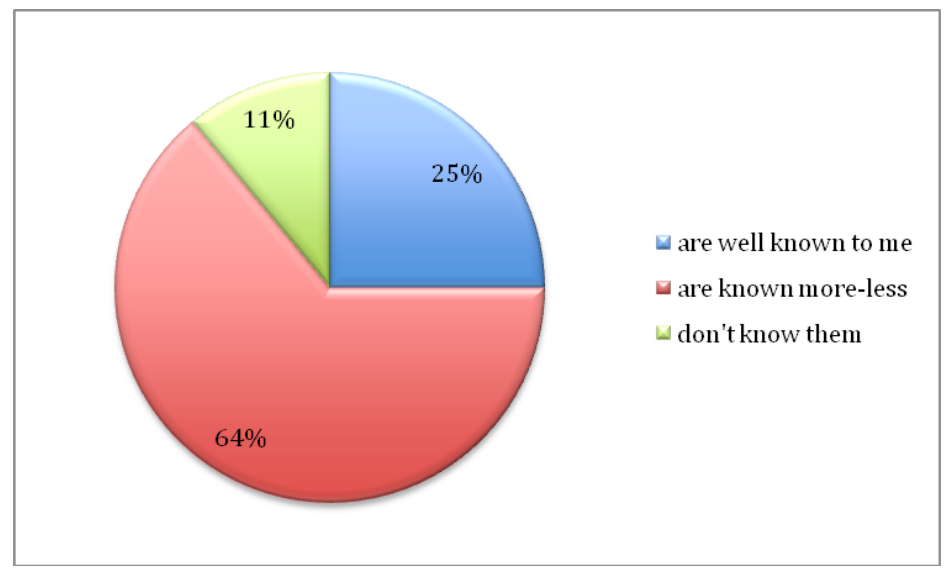

Source: Own study

Figure 10. Familiarity with company's strategic goals (London, Pune, Wroclaw)

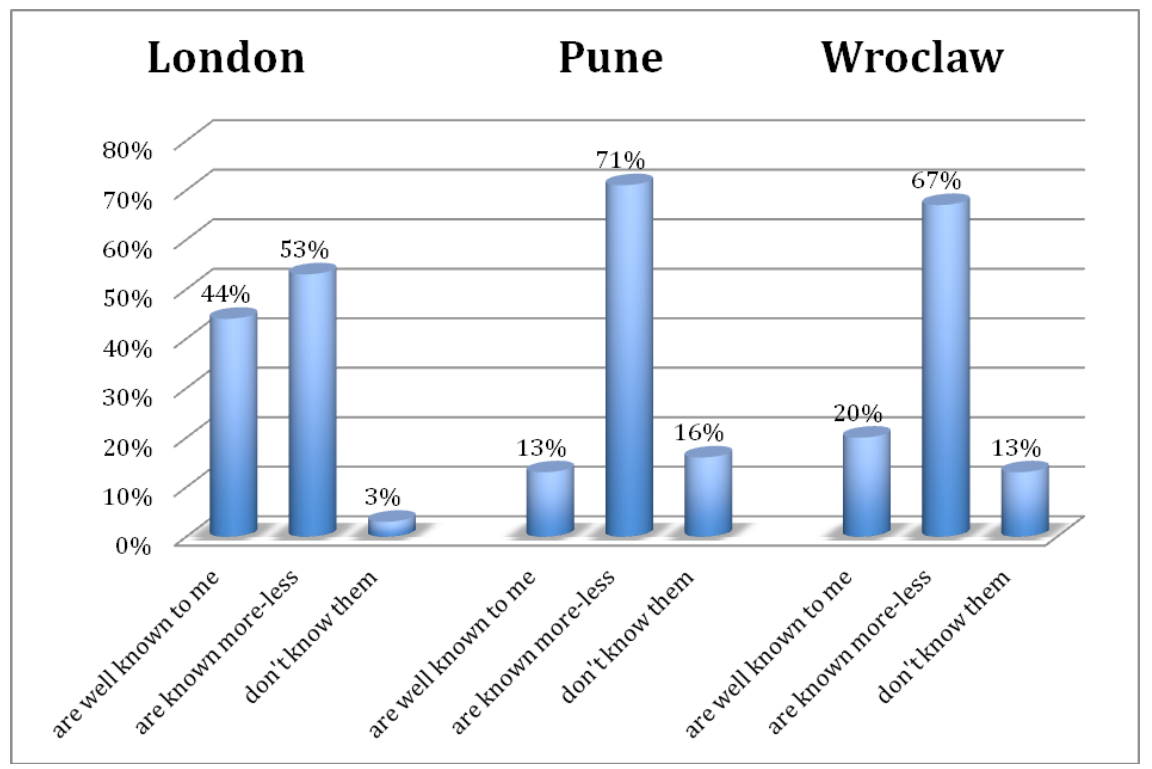

Source: Own study

The survey showed that the strongest area was represented by the staff who generally ('more or less') know the strategic objectives of the company. The respondents who are aware of the strategic objectives of the company include mainly senior officers and staff from London. The highest percentage of respondents indi- 
cating lack of knowledge of the company's goals were employees of the lowest rank, without a corporate title.

\section{Sense of attachment to the company (identification with the company)}

The survey results indicate that conformist attitudes are the strongest among $\mathrm{X}$ employees (the majority - 73\% of respondents admit that preserves passivity (neutrality) in situations when they hear the company criticized outside. At the same time, only $7 \%$ of respondents claim that they have actively expressed critical opinions about the company. There is no reason to conclude that factors such as workplace, corporate title, age, gender and nationality differentiate employees in terms of a sense of relationship with the company.

\section{Figure 11. Employees' reaction to negative opinions about the organization}

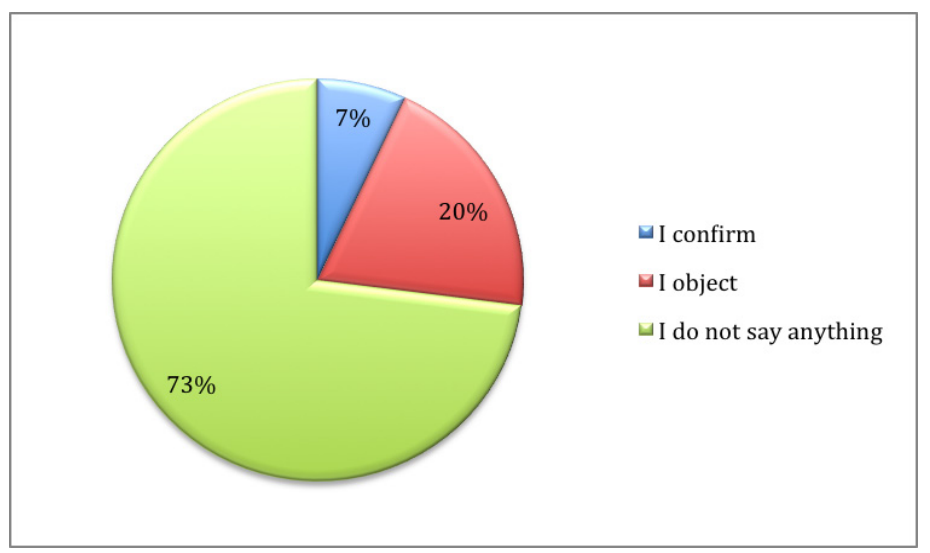

Source: Own study

The willingness to dedicate own leisure time to the company can be considered an expression of a positive attitude employee towards the company. The London employees were very likely $(87 \%)$ to indicate answers "always", "often" or "occasionally". Similarly, the people employed in Wroclaw (73\%) responded positively, regardless of their position. Quite to the contrary, the workers from Pune stated that they were not willing to stay overtime (67\%). It did not apply to foreigners working in Pune at managerial positions who declared their readiness to dedicate free time to the business and its needs. 
Figure 12. Willingness to dedicate one's own free time to the company - overall results for the three branches

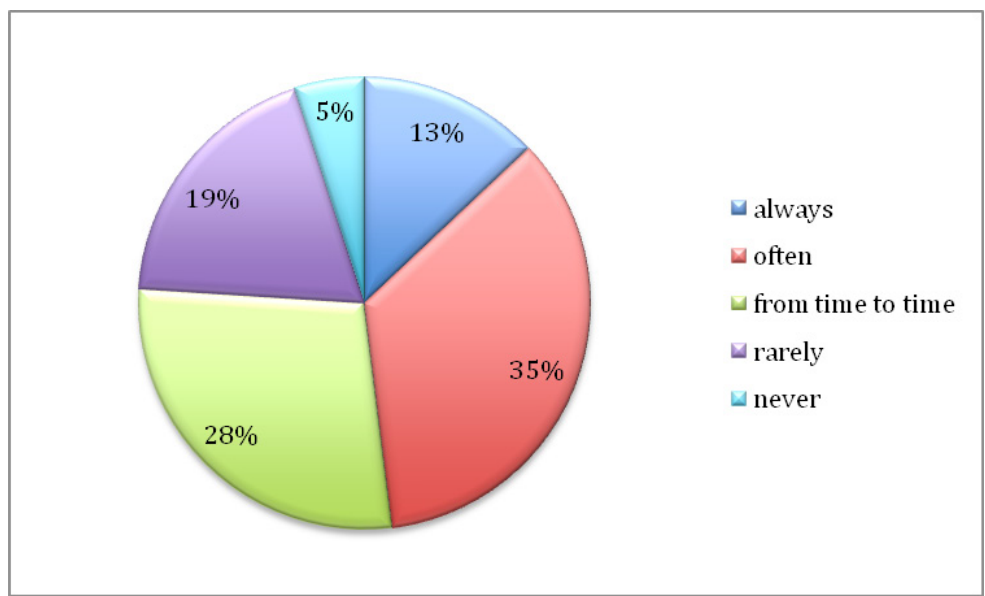

Source: Own study

\section{Readiness to change jobs}

In terms of openness to the possibility of changing jobs, respondents most frequently ( $60 \%$ of all responses) chose a conservative, cautious response ("I'm interested in such a possibility").

Figure 13. Readiness to change the jobs

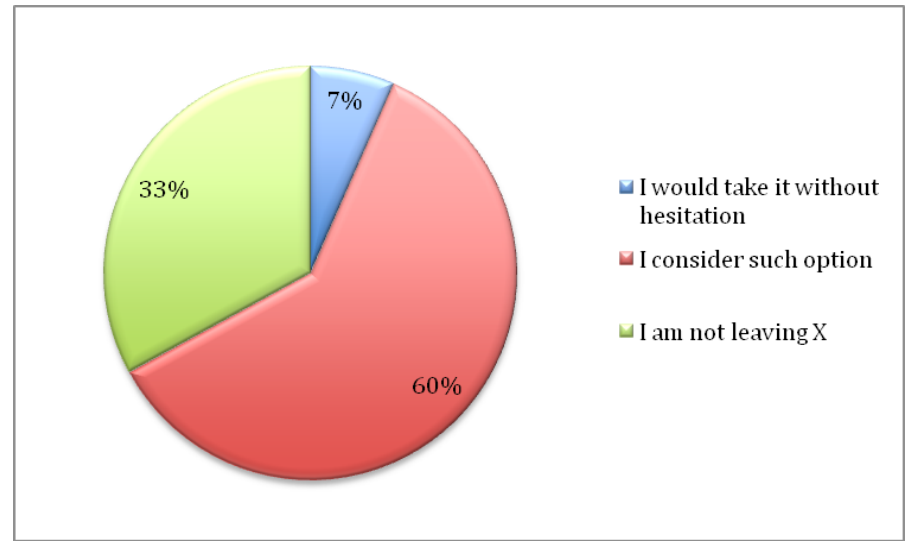

Source: Own study

The smallest share of employees willing to change jobs is accounted for by older workers above age of 40 , which can be understood both as a manifestation of a realistic assessment of the labor market, the expression of fear of change and the mani- 
festation of attachment to the company. Relatively most attached to the company proved to be the British and the Indians. The youngest respondents from Poland, on the other hand, showed a high willingness to change roles. The interest in job change was asserted by the people who had previously stated that Company $\mathrm{X}$ was a positive place to work and declared their readiness to dedicate their free time to the company. A relatively small percentage of respondents indicated an unambiguous desire to change their jobs.

Figure 14. Declaration of readiness to change jobs (London, Pune, Wroclaw)

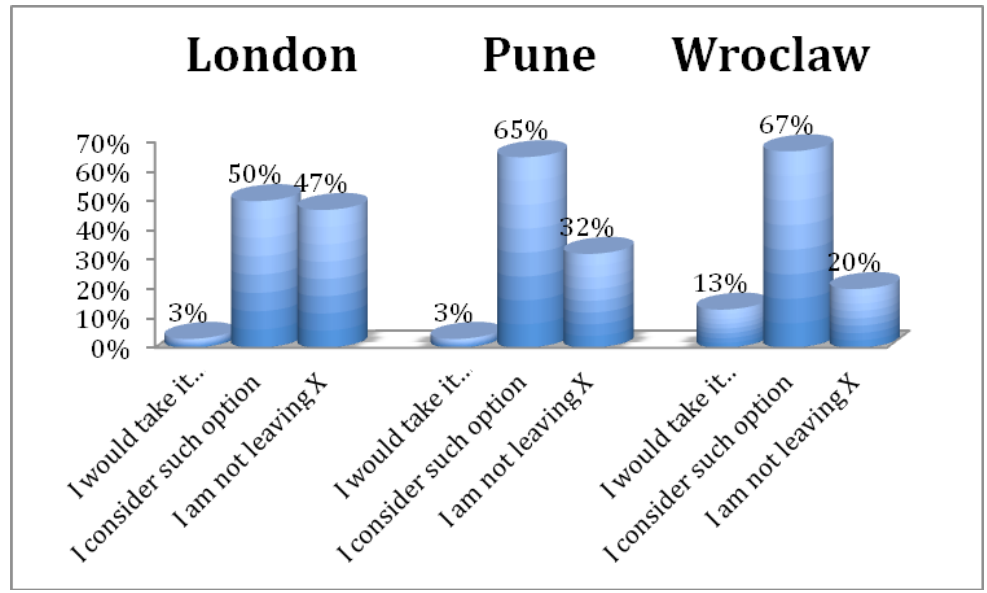

Source: Own study

Development opportunities in the current job

Respondents were asked to assess the prospects of the development of the benefits of Company X. Figure 15. illustrates the combined results for all subjects taking part in the survey and Figure 16. illustrates results for the three branches.

Figure 15. Participation in vocational trainings

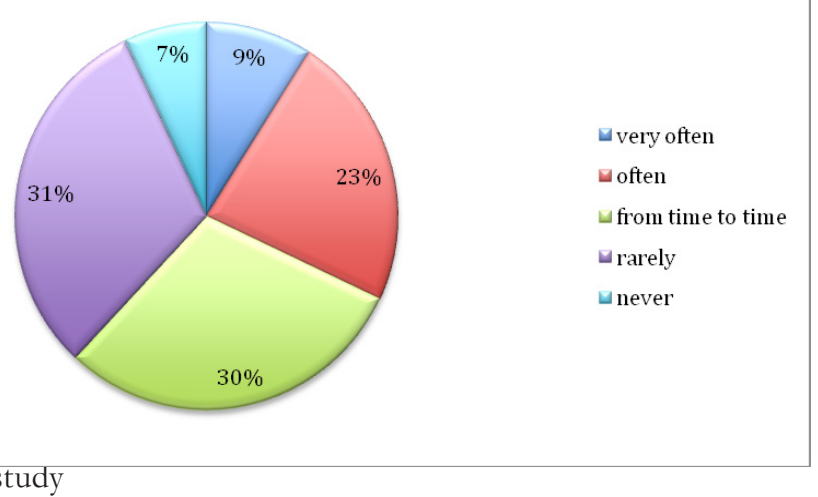


Figure 16. Participation in vocational trainings

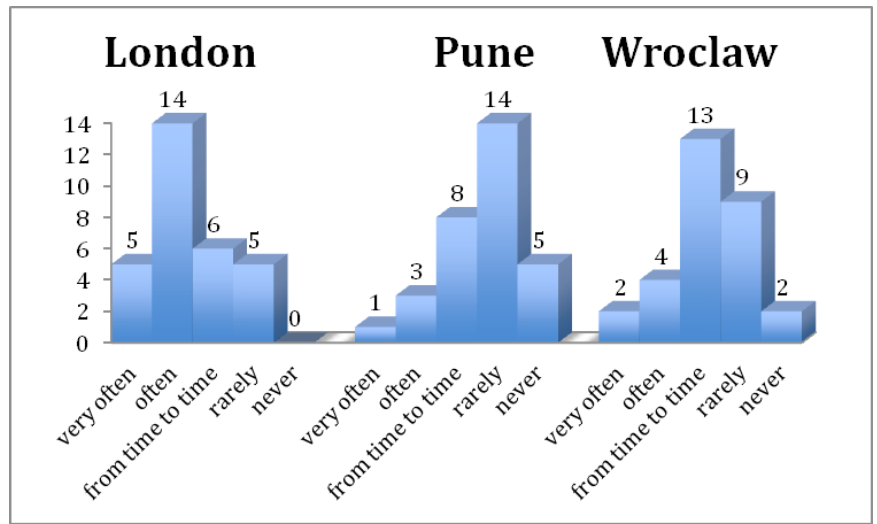

Source: Own study

The biggest opportunities in terms of development and improvement concern senior managers and people working abroad. Most of the employees checked: „from time to time”, ,rarely” or „,never”. In the opinion of the surveyed workers under 30, who do not occupy managerial positions, they have little opportunities for improvement or development.

\section{Conclusions}

The results of conducted research testify to the uniform nature of the organisational culture in the examined enterprise. In the three branches of company X, the subjects pointed to the market culture as the dominant one, regardless of the branch location (Poland, India, England). At the same time, despite the coherence of the organisational culture in the examined organisation, the results of the specific branches reveal that factors like nationality, age, occupied position differentiate the employees' levels of commitment and loyalty. The assumption that organizational culture is positively correlated with the level of commitment has been only partially confirmed and requires further verification.

The employees that manifest the highest degree of approval of the current type of organizational culture are those from the London branch, as well as officers from the two other branches. They also declare a relatively high level of commitment and loyalty towards the company. The most committed and loyal are employees who are foreigners in the examined branches. At the same time, commitment and loyalty do not coexist. However, one may talk about a trend showing a connection between employees' nationality and their commitment level. Employees from Wroclaw, despite a critical attitude towards the dominant type of organizational culture, declare a relatively high commitment to performance of their tasks and disclose low attachment to the company. As regards the studied employees of the Pune 
branch, although they were also dissatisfied with the current type of organizational culture, they manifested a low level of commitment, while declaring a relatively high loyalty towards the company. It seems that the situation can be explained by the perception of the possibilities of professional development of the employees in specific branches of the company. In the case of the Wroclaw branch workers, low assessment of the possibilities of development in company $\mathrm{X}$ coexists with a clearly lower attachment to the company. On the other hand, although the employees of the Pune branch do not consider their development opportunities as high, this does not reduce their loyalty towards the company.

The presented results do not enable clear determination of the interdependence between the nationality of employees and readiness to commit oneself and the level of loyalty, as well as the correlation between the type of organizational culture and the commitment and loyalty of employees. However, the differences between the results from the three branches (Poland, India, England) encourage continuation of that type of research.

An important question, which arises in the context of the presented results, concerns the effects of uniformization of the organizational culture in companies operating in the conditions of multiculturalism, and, above all, the impact of the organizational culture on the level of commitment and loyalty of employees of various nationalities.

\section{Bibliography}

Bugdol, M. (2006) Wartości organizacyjne, Kraków: Wydawnictwo Uniwersytetu Jagiellońskiego,

Cameron, K., and Quinn, R. (2003) Kultura organizacyjna - diagnoza $i$ żmiana, Kraków: Oficyna Ekonomiczna

Hofstede, G. (2000) Kultury i organizacje. Zaprogramowanie umystu, Warszawa: Polskie Wydawnictwo Ekonomiczne

Gajdzik, B. (2009) 'Zaangażowanie pracownicze w zarządzaniu przedsiębiorstwem', Zarzadzanie Pržedsiebiorstwem, vol. 2, no 2, pp. 23-30

Juang, L., and Matsumoto, D. (2010) Psychologia miedrykulturowa, Gdańsk: Gdańskie Wydawnictwo Psychologiczne

Markowski, K., Rożnowski, B., Bryk, D., and Konefał, K.(2010) 'Pracownik w organizacji', in Przedsiebiorcy wobec wyzwan $i$ zagrożen, Lublin: Europejski Dom Spotkań - Fundacja Nowy Staw

Meyer, J.P., Allen N.J. and Smith, A.C. (1993) 'Commitment to Organizations and Occupations: Extensions and Test of Three-component Conceptualization', Journal of Applied Psychology, vol. 78, pp. 538-551

Schein, E.(1984) 'Coming to a New Awareness of Organizational Culture', Sloan Management Review, vol. 25, no 2, pp. 3-16 
Schein E.(2004) Organizational Culture and Leadership, London: John Wiley \& Sons, Inc.

Schultz, D. and Schultz, S. E.(2008) Psychologia a wyzwania drisiejszej pracy, Warszawa: Wydawnictwo Naukowe PWN

Sikorski, C. (2002) Kultura organizacyjna, Warszawa: CH Beck 